\title{
MORPHO-PHYSIOLOGICAL CHANGES IN PINEAPPLE PLANTLETS [Ananas comosus (L.) Merr.] DURING ACCLIMATIZATION
}

\author{
Mudanças morfofisiológicas em plântulas de abacaxi \\ [Ananas comosus (L.) Merr.] durante a aclimatização
}

\author{
Ariel Villalobo' ${ }^{1}$ Justo González² ${ }^{2}$ Ramón Santos², Romelio Rodríguez ${ }^{3}$
}

\begin{abstract}
Pineapple producing countries lack good quality propagation material to expand cultivars into new areas. Previously, research protocols may increase the offer of high quality plantlets and speed the introduction of new pineapple cultivars. The present work is to evaluate the morpho-physiological changes in plantlets of pineapple [Ananas comosus (L.) Merr. 'MD-2'] during the acclimatization phase. Plantlets were acclimatized under $80 \%$ relative humidity, $25.5{ }^{\circ} \mathrm{C}$ temperature and photosynthetic photon flux of $400-500 \mu \mathrm{mol} \mathrm{m}^{-2} \mathrm{~s}^{-1}$ as average for $45 \mathrm{~d}$ under natural photoperiods. All measurements (plant length, number of leaves and roots, fresh weight, width and length of leaf ' $\mathrm{D}$ ', net photosynthesis and total transpiration rate) were carried out at the end of in vitro rooting phase coincident with $0 \mathrm{~d}$ of acclimatization and at 15,30 and $45 \mathrm{~d}$ thereafter. Photosynthetic activity of in vitro plantlets did not increase during the first $30 \mathrm{~d}$ of the acclimatization phase. After $30 \mathrm{~d}$, photosynthetic activity ranged from 5.72 to $9.36 \mu \mathrm{mol} \mathrm{CO}$ $\mathrm{m}^{-2} \mathrm{~s}^{-1}$ while total transpiration ranged from 6.0 to $1.42 \mathrm{mmol} \mathrm{H}_{2} \mathrm{O} \mathrm{m}^{-2} \mathrm{~s}^{-1}$. During the first 30 days there were no significant differences in number of leaves, length or width of the longest ('D') leaf $(\mathrm{cm})$ or plant length $(\mathrm{cm})$. However, after 45 days plant fresh weight $(\mathrm{g})$, length and width of the ' $\mathrm{D}$ ' leaf $(\mathrm{cm})$ and root number all increased significantly, while transpiration $\left(\mathrm{mmol}_{2} \mathrm{O} \mathrm{m}^{-2} \mathrm{~s}^{-1}\right)$ declined. There were small but significant decreases in chlorophyll a and $\mathrm{b}\left(\mu \mathrm{g} \mathrm{g}^{-1} \mathrm{mf}\right.$.). Increased photosynthetic activity after $30 \mathrm{~d}$ shows that the increase in light intensity and the reduction of relative humidity during acclimatization did not constitute inhibitory factors.
\end{abstract}

Index terms: Chlorophyll, ex vitro conditions, photosynthesis, transpiration.

\section{RESUMO}

Os países produtores do abacaxi precisam de mudas de boa qualidade para a introdução de novas culturas nas áreas de cultivo. Os protocolos de pesquisa podem aumentar a oferta de mudas de alta qualidade e acelerar a introdução de novas culturas do abacaxi. $\mathrm{O}$ estudo apresentado teve como objetivo avaliar as alterações morfofisiológicas de mudas de abacaxi [Ananas comosus (L.) Merr. 'MD-2'], durante a fase de aclimatação. As plantas foram aclimatizadas baseadas em um regímen de $80 \%$ de humidade relativa, uma temperatura de $25^{\circ} \mathrm{C}$ e um fluxo médio de fótones fotossinteticamente ativos de $400-500 \mu \mathrm{mol} \mathrm{m} \mathrm{m}^{-2} \mathrm{~s}^{-1}$, durante 45 dias em condições naturais de iluminação. As medições todas (comprimento da planta, número de folhas, comprimento, largura da folha maior ' $D$ ', taxa fossintetica e taxa transpiratória total) foram feitas no final da fase do enraizamento in vitro a coincidir com a aclimatização no período de 0,15, 30 e 45 dias após aclimatização. Depois de 30 dias, a atividade fotossintética variou entre 5,72 e 9,36 $\mu \mathrm{mol} \mathrm{CO}_{2} \mathrm{~m}^{-2} \mathrm{~s}^{-1}$, enquanto a transpiração total variou de 6,0 a $1,42 \mathrm{mmol} \mathrm{H}_{2} \mathrm{O} \mathrm{m}^{-2} \mathrm{~s}^{-1}$. Durante os primeiros 30 dias, não foram registradas diferenças significativas entre o e comprimento da planta, número de folhas e comprimento e largura da folha maior ' $\mathrm{D}$ '. No entanto, após 45 dias a massa fresca da planta $(\mathrm{g})$, comprimento e largura da lâmina ' $\mathrm{D}$ ' $(\mathrm{cm})$ e o número de raízes aumentarem significativamente, enquanto a transpiração (mmol $\left.\mathrm{H}_{2} \mathrm{O} \mathrm{m}^{-2} \mathrm{~s}^{-1}\right)$ foi reduzida. As clorofilas $a \mathrm{e} b\left(\mu \mathrm{g} \mathrm{g}^{-1} \mathrm{mf}\right)$ diminuíram e mostraram diferenças pequenas, mas significativas. $\mathrm{O}$ aumento da atividade fotossintética após 30 dias mostrou que o aumento da intensidade luminosa e redução da umidade relativa não são fatores inibidores desta atividade durante a aclimatização.

Termos para indexação: Clorofila, condições ex vitro, fotossíntese, transpiração.

(Received in august 21, 2012 and approved in november 08, 2012)

\section{INTRODUCTION}

Pineapple [Ananas comosus (L.) Merr.] is vegetatively propagated so expanding the available supply of planting material required to expand production in new areas or introduce a new cultivar is an expensive and time consuming process. Based on typical planting densities for various cultivars, one hectare of the crop requires from
35000 to 75000 propagules (BARTHOLOMEW; PAULL; ROHRBACK, 2003).

The MD-2 cultivar, developed by Del Monte Fresh Produce International Inc., has almost completely taken over the international fresh fruit market (LOEILLET; DAWSON; PAQUI, 2011). In order for the pineapple industries to remain competitive, it is imperative that they expand plantings of 'MD-2' pineapple on a commercial

\footnotetext{
1 University of Ciego de Avila - Agronomic Department - Ciego de Avila - Cuba

'University of Ciego de Avila - Agro-Biology Laboratory - Bioplant Center - Cuba

${ }^{3}$ University of Ciego de Avila - Agro-Biology Laboratory - 69450 - Bioplant Center - Cuba - romelio@bioplantas.cu
}

Ciênc. agrotec., Lavras, v. 36, n. 6, p. 624-630, nov./dez., 2012 
scale (BARTHOLOMEW et al., 2009). Rapid expansion of planting material requires the implementation of a meristem bank to establish plantlets production schemes with the use of biotechnology techniques (LEAL; COPPENS D'EECKENBRUGGE, 1996).

The key means of regeneration is the use of meristematic tips (BOTELLA; FAIRBAIN, 2005). All these protocols have disadvantages related with the low coefficients of multiplication and the high cost and the low possibility of automation (WATT, 2012). That is why the explosive expansion of this industry depends on the existence of new technologies to facilitate automation and improved protocols to optimize the acclimatization of plants (KITTO, 1999).

However, the potential use of these procedures is limited by the low survival rates and plant growth during the acclimatization stage. Plants cultured in vitro are exposed to high levels of organic and inorganic nutrients, high relative humidity, low light intensity, and limited exchange of $\mathrm{CO}_{2}$ and $\mathrm{O}_{2}$. As a result, in vitro cultivated plants have morphological and physiological abnormalities (BARBOZA et al., 2006). Those modifications make them very sensitive to the abrupt environmental changes experienced when they are removed from culture containers and placed under ex vitro conditions (KELLER; LUTTGE, 2005; BRAGA et al., 2011). As a result, a gradual acclimatization period is normally required after ex vitro transplantation to reduce stress as in vitro plants progressively acclimatize to the new growing condition (YANES; GONZÁLEZ; RODRÍGUEZ, 2000).

Bioplant Center developed a novel protocol for the production of in vitro cultivated plants based on the use of liquid medium and temporary immersion technology coupled with the implementation of a semiautomatic system. The system reduces the time required to generate sufficient quantities of plantlets for the creation of high quality pineapple plantlets banks. Using this technology, a pilot plant produced about one million 'MD-2' plantlets in a small growth chamber (ESCALONA et al., 1999). However, little is known about the morpho-physiological changes undergone by 'MD-2' plantlets during the acclimatization phase of the process. The objectives of this research were to characterize the morphological and physiological changes that occurred in plantlets during the acclimatization process. It is expected that the information would guide further research on improvements in acclimatization that would speed the process or improve rates of establishment under field conditions.

\section{MATERIALS AND METHODS}

\section{Plant material and growth conditions.}

Pineapple plantlets (Ananas comosus 'MD-2') were micropropagated according to the protocol proposed by Daquinta and Benegas (1997) using the crown buds as explants.

For Phase I (in vitro establishment), the culture medium contained $10 \mathrm{mg} \mathrm{L}^{-1}$ Murashige and Skoog (1962) salts (MS), $1.0 \mathrm{mg} \mathrm{L}^{-1}$ thiamine, $0.1 \mathrm{~g} \mathrm{~L}^{-1}$ myo-inositol, 1.0 $\mathrm{mg} \mathrm{L}^{-1}$ naphthaleneacetic acid (NAA), $30 \mathrm{~g} \mathrm{~L}^{-1}$ sucrose, 1.0 $\mathrm{mg} \mathrm{L}^{-1}$ 6-benzylamino purine (BAP) and $6.5 \mathrm{mg} \mathrm{L}^{-1}$ agar. The culture medium for Phase II (multiplication) contained $10 \mathrm{mg} \mathrm{L}^{-1} \mathrm{MS}$ salts, $1.0 \mathrm{mg} \mathrm{L}^{-1}$ thiamine, $0.1 \mathrm{mg} \mathrm{L}^{-1}$ myoinositol, $0.3 \mathrm{mg} \mathrm{L}^{-1} \mathrm{NAA}, 30 \mathrm{~g} \mathrm{~L}^{-1}$ sucrose and $2.1 \mathrm{mg} \mathrm{L}^{-1}$ BAP. For Phase III (pre-elongation) culture medium was prepared with $10 \mathrm{mg} \mathrm{L}^{-1} \mathrm{MS}$ salts, $1.0 \mathrm{mg} \mathrm{L}^{-1}$ thiamine, 0.1 $\mathrm{mg} \mathrm{L}^{-1}$ myo-inositol, $0.5 \mathrm{mg} \mathrm{L}^{-1}$ NAA and $30 \mathrm{~g} \mathrm{~L}^{-1}$ sucrose. For the phase IV (rooting), the culture medium contained $10 \mathrm{mg} \mathrm{L}^{-1} \mathrm{MS}$ salts, $1.0 \mathrm{mg} \mathrm{L}^{-1}$ thiamine, $10 \mathrm{mg} \mathrm{L}^{-1}$ myoinositol, $0.5 \mathrm{mg} \mathrm{L}^{-1} \mathrm{NAA}$ and $30 \mathrm{~g} \mathrm{~L}^{-1}$ sucrose. Prior to sterilization, the medium $\mathrm{pH}$ was adjusted to 5.7 for all phases of the in vitro culture. Each in vitro phase lasted 45 days.

\section{In vitro culture conditions.}

All in vitro manipulations were performed in aseptic conditions. The culture media were sterilized by autoclaving at $121^{\circ} \mathrm{C}$ at $118 \mathrm{kPa}$ pressure. The plantlets were grown in transparent magenta plastic containers $(7.2$ x $8.6 \times 9.2(\mathrm{H}) \mathrm{cm}$ ) with $40 \mathrm{~mL}$ of liquid medium. The photoperiod was of $16 \mathrm{~h}$ at a photosynthetic photon flux (PPF) of $75 \mu \mathrm{mol} \mathrm{m} \mathrm{m}^{-2} \mathrm{~s}^{-1}$ and $26 \pm 2^{\circ} \mathrm{C}$ of temperature during all phases.

\section{Environmental conditions in acclimatization phase.}

Uniform micropropagated plantlets of $\geq 4.0 \mathrm{~cm}$ height, 7.0-8.0 g fresh weight and containing 5-6 true leaves were selected from the plastic culture vessels (ESCALONA et al., 1999), dipped in $3.0 \mathrm{~mL} \mathrm{~L}^{-1}$ Previcur Energy ${ }^{\circledR}$ (Bayer Cropscience) for 5 minutes and planted in 1:1 (v:v) red ferralytic soil and filter cake (derived from sugarcane bagasse) in polyethylene bags $\left(396.26 \mathrm{~cm}^{3}\right)$ as containers for acclimatization (VILLALOBOS et al., 2012). Plantlets were acclimatized under $80 \%$ relative humidity $(\mathrm{RH}), 25.5^{\circ}$ $\mathrm{C}$ temperature and photosynthetic photon flux (PPF) of $400-500 \mu \mathrm{mol} \mathrm{m} \mathrm{m}^{-2} \mathrm{~s}^{-1}$ as average for $45 \mathrm{~d}$ under natural photoperiods. During the first week, plants were misted for 15 seconds every 45 minutes beginning at 9:00 am each 
day. A foliar fertilizer mix containing $16.0 \mathrm{~g}$ of crystalline $\mathrm{N}$ P-K and $1.0 \mathrm{~g}$ of Multimicro Combi (Haifa Chemicals Ltd., Haifa Bay 26120, Israel) in $16 \mathrm{~L}$ of water was applied every ten days.

Morpho-physiological measurements were carried out at the end of in vitro rooting phase coincident with $0 \mathrm{~d}$ of acclimatization and at 15, 30 and $45 \mathrm{~d}$ thereafter.

\section{Morphological and physiological analysis.}

Forty plants were collected at each time interval and data were taken on plant length $(\mathrm{cm})$, number of leaves and roots; fresh weight (g), width and length of leaf ' $\mathrm{D}$ ', defined as a leaf forming a 45 degrees with the vertical axis.

Chlorophyll was extracted from five leaf disks $(0.28$ $\mathrm{cm}^{2}$ ) taken from the ' $D$ ' leaves of five plantlets.

Disks were incubated in $3 \mathrm{~mL}$ DMSO at $65^{\circ} \mathrm{C}$ for 1 hour, and absorbance was measured at 645 and $663 \mathrm{~nm}$. The chlorophyll concentration of the extracts was calculated using the equations described by Porra et al. (2002).

\section{Photosynthesis measurements.}

Net photosynthesis $\left(\mathrm{A}, \mu \mathrm{mol} \mathrm{m} \mathrm{m}^{-2} \mathrm{~s}^{-1}\right)$ was measured at the ambient relative humidity and air temperature. The analyzer and cuvette (PP Systems CIRAS-2 Portable Photosynthesis System and PLC6 $2.5 \mathrm{~cm}^{2}$ cuvette, http:// www.ppsystems.com/) were automatically calibrated before every measurement. Light was fixed at $600 \mu \mathrm{mol} \mathrm{m} \mathrm{m}^{-2} \mathrm{~s}^{-1}$ for the determination of the $\mathrm{A} / \mathrm{Ci}$ curve, while the $\mathrm{CO}_{2}$ was fixed at $400 \mu \mathrm{mol} \mathrm{mol}^{-1}$, these values were obtained from saturation curve of light and $\mathrm{CO}_{2}$ in pineapple plants.

Measurement of $A$ and total transpiration rate $(\mathrm{T}$, mmol $\mathrm{H}_{2} \mathrm{O} \mathrm{m}^{-2} \mathrm{~s}^{-1}$ ) were always made on the youngest fully expanded leaves and between 9:00 am and 10:00 am.

\section{Statistical analysis.}

At each sampling day, six plants were randomly selected to measure photosynthesis and transpiration, 40 for counting leaves, width and length of leaf ' $\mathrm{D}$ ' (cm), plant length, root number, 20 for measuring fresh weight and 10 for measuring chlorophyll content.

Analysis of variance was conducted using SPSS Program. Duncan's multiple range tests and Student's tdistribution were used for mean separation at $\mathrm{p}<0.05$ level.

\section{RESULTS AND DISCUSSION}

Total transpiration of in vitro leaves was highest at $0 \mathrm{~d}$ and declined significantly by $15 \mathrm{~d}$ after transfer to $e x$ vitro conditions, after which it remained constant until the end of the experiment (Figure 1 A). Leaves initially became shorter and wider when plantlets were subjected to the higher light levels of the acclimatizing environment (Table 1). The low light levels during in vitro culture likely caused some etiolation of the leaves.

It appears that in only $15 \mathrm{~d}$, the stomata become functional to control water loss since transpiration was stable from that point on. This observation is consistent with the fact that during acclimatization, the transpiration is gradually reduced as stomata become functional and cuticular water loss declines (HERRERA, 2009). When stomatal and cuticular transpiration rates in in vitro leaves are very high it is difficult to maintain plant turgidity after transplanting ex vitro (SEON et al., 2000).

Photosynthesis at $0 \mathrm{~d}$ was low at the end of in vitro phase and remained for the first 30 days after transfer to $e x$ vitro conditions (Figure 1 B). The significantly higher level
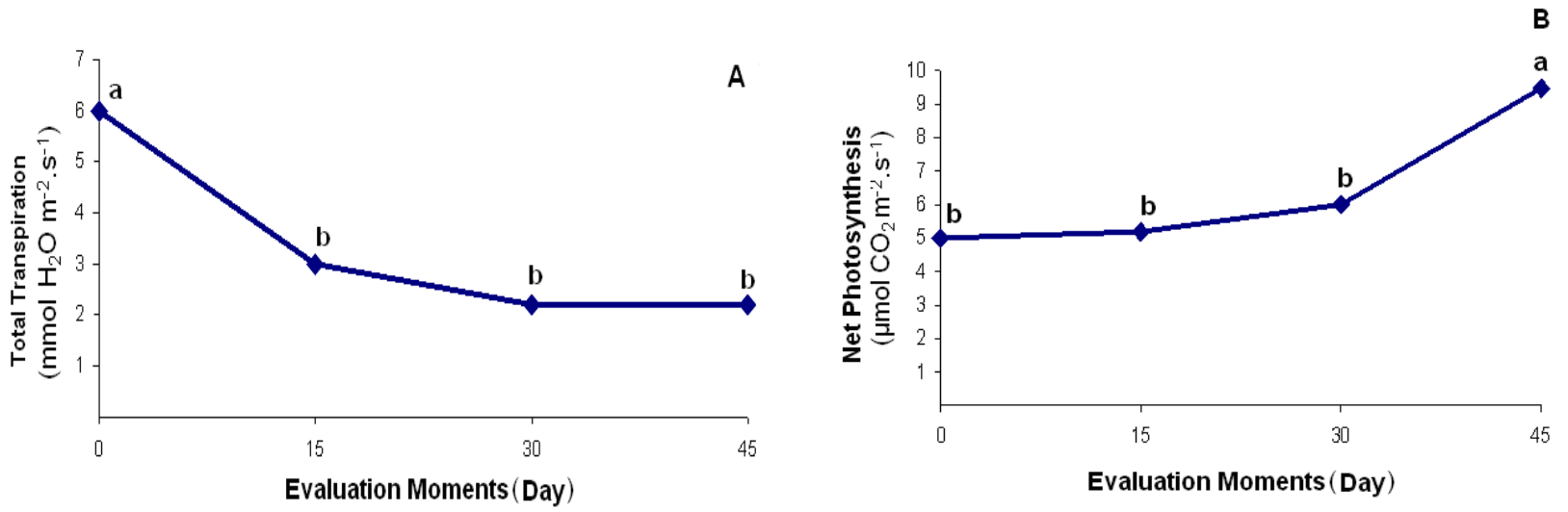

Figure 1 - (A) Behavior of total transpiration rate $\left(\mathrm{mmol} \mathrm{H}_{2} \mathrm{O} \mathrm{m}^{-2} \mathrm{~s}^{-1}\right)$ and $(\mathrm{B})$ net photosynthesis $\left(\mu \mathrm{mol} \mathrm{CO}_{2} \mathrm{~m}^{-2} \mathrm{~s}^{-1}\right)$ in pineapple plantlets (Ananas comosus 'MD-2') during acclimatization. Means followed by different letters in rows are significantly different using ANOVA, Duncan's test, $\mathrm{p}<0.05$.

Ciênc. agrotec., Lavras, v. 36, n. 6, p. 624-630, nov./dez., 2012 
of photosynthesis at $45 \mathrm{~d}$ demonstrated that pineapple plantlets had adapted to increment of light intensity in the acclimatizing environment. The decline in transpiration and increase in $\mathrm{CO}_{2}$ fixation by day 45 might indicate the plant was adapted to the new conditions during acclimatization phase and maybe of plants having Crassulacean acid metabolism(ZHU; BARTHOLOMEW; GOLDSTEIN, 2005). Ceusters et al., (2010) found in bromeliad, a photosynthetic plasticity in response to a range of environmental factors that include [CO2], water availability, light intensity and temperature.

Cote, Folliot and Andre (1993) found that in vitro pineapple plants required a few months and a plant fresh weight of about $30 \mathrm{~g}$ to complete the transition from C3dependent photosynthesis to predominantly CAM assimilation. Thus, it seems unlikely that plants in this study, which weighed only about $11 \mathrm{~g}$ at 45 days after transfer to ex vitro conditions (Table 2), would demonstrate significant CAM activity.

In the evaluation at ' $D$ ' leaf width, it was unchanged at $15 \mathrm{~d}$ after plant transference to acclimatization after which width increased progressively with time to day 45 (Table 1). Plant length was significantly less after 15 and $30 \mathrm{~d}$ than it was at day 0 , but by day 45 had regained the height at day 0 .

Aragon et al. (2012) found that stress imposed by water deficit and higher photosynthetic photon flux switched pineapple plants from C3 to CAM behavior. In our results we can find more number of roots, higher fresh weight and photosynthetic activity at $45 \mathrm{~d}$ in acclimatization period to report for this author at $56 \mathrm{~d}$ in CAM induced pineapple. Maybe, the environmental conditions used in aclimatización process (increase in light intensity and quality of natural light) were decisive factors for it results.

The effects of increment in light intensity and the gradual reduction of relative humidity at early stage were demonstrated in pineapple plantlets (Ananas comosus) by Yanes, González and Rodríguez (2000) and Silva et al. (2008).

Batagin et al. (2009) found an increase on cuticle thickness, on wavy contours of epidermal cells, and on the distribution and quantity of mesophyll fibers were observed during acclimatization process, evidencing the light conditions interference in morphological characteristics of the pineapple plantlets. In vitro propagation of pineapple has demonstrated that light is the factor with more influence on plant quality (GONZALEZ et al., 2005) and provides better agronomic and anatomical change during the acclimatization phase (DAMASCENO; SOUZA; GOMES, 2008).

During the acclimatization phase, plantlet increased 1.41 the root number, while stem diameter was $0.32 \mathrm{~cm}$ and the plant fresh weight reached $3.25 \mathrm{~g}$. The main cause of fresh weight increase was found in the new emission of root, stem diameter, width of leaves and length of plants

Table 1 - Change of morphological variables of pineapple plantlets (Ananas comosus 'MD-2') during acclimatization.

\begin{tabular}{|c|c|c|c|c|c|}
\hline \multicolumn{6}{|c|}{ Time of evaluation (days) } \\
\hline Variables & 0 & 15 & 30 & 45 & SE \\
\hline Number of Leaves & $9.80 \mathrm{a}$ & $8.76 \mathrm{c}$ & $9.01 \mathrm{c}$ & $9.36 \mathrm{~b}$ & 0.090 \\
\hline Width of leave 'D'(cm) & $1.40 \mathrm{c}$ & $1.54 \mathrm{c}$ & $1.73 \mathrm{~b}$ & $2.02 \mathrm{a}$ & 0.024 \\
\hline Length of leave 'D' (cm) & $10.17 \mathrm{a}$ & $8.73 \mathrm{c}$ & $9.24 \mathrm{~b}$ & $9.56 \mathrm{~b}$ & 0.140 \\
\hline Length of Plant $(\mathrm{cm})$ & $10.24 \mathrm{a}$ & $9.01 \mathrm{c}$ & $9.66 \mathrm{~b}$ & $10.37 \mathrm{a}$ & 0.110 \\
\hline
\end{tabular}

Means followed by different letters in rows are significantly different using ANOVA, Duncan's test, $\mathrm{p}<0.05$.

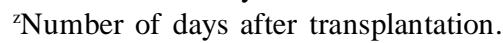

Table 2 - Change in morphological variables of pineapple plantlets (Ananas comosus 'MD-2') at the initial and final evaluation during acclimatization.

\begin{tabular}{lccc}
\hline Variables & 0 & 45 days $^{\mathrm{Z}}$ & SE \\
\hline Root number & $5.90 \mathrm{~b}$ & $7.31 \mathrm{a}$ & 0.040 \\
Stem diameter $(\mathrm{cm})$ & $0.73 \mathrm{~b}$ & $1.05 \mathrm{a}$ & 0.014 \\
Plant fresh weght $(\mathrm{g})$ & $8.10 \mathrm{~b}$ & $11.35 \mathrm{a}$ & 0.060 \\
\hline
\end{tabular}

Means with different letters in rows indicate significant (Student's t- $\mathrm{p}<0.05$ ).

${ }^{\mathrm{z}}$ Number of days after transplantation. 
leaves during the experiment. In pineapple, the major drymatter accumulation is associated with a high leaf area index and the ability to maintain their photosynthetic capacity for long periods of time (BARTHOLOMEW; MALÉZIEUX, 1994). However, in pineapple plantlets the fresh weight increased significant during 45 days, presumably due the new environmental conditions and the photoautotrophic behavior of the plantlets.

Generally, it is recognized that environmental change during in vitro to ex vitro conditions cause stress in plants, expressed in terms of accumulation of abscisic acid (ABA), proline and reactive oxygen species (CARVALHO et al., 2006; BATROVA; POSPOSILOVA; SYNKOVA, 2008). However, results on in vitro pineapple have shown that it is possible to affect the carbon metabolism by changing the environmental temperature during the light and the dark period (NIEVOLA et al., 2005). Temperature and plant heights also had influences notably in the morphologycal variable in plants cultivated in a greenhouse (DAMASCENO; SOUZA; GOMES, 2008). In our results, apparently, no prolonged stress was observed during acclimatization phase, demonstrated by the growth of the evaluated variables in all process.
After transfer of plantlets to acclimatization condition a sharp and not significant decrease in chlorophyll a and $b$ was observed during the first 15 days (Table 3) and was constant until $45 \mathrm{~d}$. The chlorophyll a and $\mathrm{b}$ content continued to decrease until $45 \mathrm{~d}$ (8.1 and $3.8 \mu \mathrm{g} \mathrm{g}^{-1} \mathrm{FW}$ respectively). This higher content in chlorophyll in young in vitro leaves is indicative of adaptation to shade. Under these conditions, the light intercepting units are extensive, and higher chlorophyll are associated with higher investment of the plant into light harvesting complex of photosystem II (LHC II), and antenna pigments. This might be explained by a rapid dismantling of the light harvesting antenna to avoid overreduction of the photosynthetic electron chain, which may lead to photoinhibition (BATROVA; POSPOSILOVA; SYNKOVA, 2008).

Chlorophyll $\mathrm{a} / \mathrm{b}$ ratio showed no significant reduction $\left(0.02 \mu \mathrm{g} \mathrm{g}^{-1} \mathrm{FW}\right)$ at the times of transfer to different environmental conditions during the first $30 \mathrm{~d}$. This is not in contradiction with the result found by Fila et al. (2006) that recorded high chlorophyll contents in plantlets growth under in vitro condition compared with ex vitro acclimatized.

Table 3 - Change in chlorophyll a, chlorophyll b, and total chlorophyll content in pineapple plantlets during acclimatization phase.

\begin{tabular}{crrrr}
\hline Chlorophyll b $\left(\mu \mathrm{g} \mathrm{g}^{-1} \mathrm{FW}\right)$ & 0 & 15 & 30 & 45 days $^{\mathrm{z}}$ \\
\hline $\mathrm{Chl} \mathrm{a}$ & $90.1 \mathrm{a}$ & $87.0 \mathrm{ab}$ & $85.3 \mathrm{ab}$ & $82.0 \mathrm{~b}$ \\
$\mathrm{Chl} \mathrm{b}$ & $70.0 \mathrm{a}$ & $68.2 \mathrm{ab}$ & $67.4 \mathrm{~b}$ & $66.2 \mathrm{~b}$ \\
$\mathrm{Chl} \mathrm{a+b}$ & $160.1 \mathrm{a}$ & $155.2 \mathrm{ab}$ & $152.7 \mathrm{~b}$ & $148.2 \mathrm{~b}$ \\
$\mathrm{Chl} \mathrm{a} / \mathrm{b}$ & $1.28 \mathrm{a}$ & $1.27 \mathrm{a}$ & $1.26 \mathrm{ab}$ & $1.23 \mathrm{~b}$
\end{tabular}

Means followed by different letters in rows are significantly different using ANOVA, Duncan's test, $\mathrm{p}<0.05$.

${ }^{\mathrm{z}}$ Number of days after transplantation. 


\section{CONCLUSIONS}

At 30 days, pineapple plantlets showed photoautotrophic conduct, due to the new formation of roots and new emission of photoautotrophic leaves.

Photosynthetic activity was tolerant of relatively high environmental stress. Thus, there was significant acclimation of photosynthesis until a maximum was reached at $45 \mathrm{~d}$ in the ex vitro environment, which suggests that high photosynthetic capacity was acquired slowly, and thus impacted strongly on subsequent growth and physiological development of the plants while chlorophyll content showed no significant reduction during the first $30 \mathrm{~d}$.

\section{ACKNOWLEDGEMENTS}

The authors would like to acknowledge Dr. PD Bartholomew for the appreciate collaboration in critically reading the manuscript and the English correction.

\section{REFERENCES}

ARAGON, C. et al. The physiology of ex vitro pineapple (Ananas comosus (L.) Merr. var MD-2) as CAM or C3 is regulated by the environmental conditions. Plant Cell Reports, Berlin, v.31, p.57-769, 2012.

BARBOZA, S.B.S.C. et al. Anatomia foliar de plantas micropropagadas de abacaxi. Pesquisa Agropecuária Brasileira, Brasília, v.41, p.185-194, 2006.

BARTHOLOMEW, D.P. et al. Botany, production and uses. CABI Publishing, Wallingford, UK., 301 p., 2003.

BARTHOLOMEW, D.P. MD-2 Pineapple transforms the world's pineapple fresh fruit export industry. Pineapple News, International Society of Horticultural Science. Hawaii, v.8, p.2-5, 2009.

BARTHOLOMEW, D.P.; MALÉZIEUX, E.P. The Pineapple. In: SCHAFFER, B., ANDERSEN, P.C. Handbook of environmental physiology of fruit crops.: CRC Press, Boca Raton, v.2, p.243-291, 1994.

BATAGIN, K.D. et al. Morphological alterations in leave of micropropagated pineapple plants cv. IAC "Gomo-de-mel”" acclimatizated in different conditions of luminosity. Acta Botanica Brasilica, Sao Paulo, v.23, n.1, p.85-92, 2009.

BATROVA, P.; POSPOSILOVA, J.; SYNKOVA, $\mathrm{H}$. Production of reactive oxygen species and development of antioxidative systems during in vitro growth and $e x$ vitro transfer. Biologia Plantarum, Prague, v.52, p.413422, 2008.

BOTELLA, J.R.; FAIRBAIRN, D.J. Present and future potential of pineapple biotechnology. Acta Horticulturae, Wageningen, v.666, p.23-28, 2005.

BRAGA, F.T. et al. Alterações morfofisiolócias de plantas de abacaxizeiro influenciadas por diferentes substratos durante o processo de aclimatização. Ciência Agrotecnologia, Lavras, v.35, n.5, p.863-868, 2011.

CARVALHO, L. et al. Activation of the ascorbateglutathione cycles is an early response of micropropagated Vitis vinifera L. explants transferred to ex vitro. International Journal of Plant Science, Oxford, v.167, p.759-770, 2006.

CEUSTERS, J. et al. Seasonal influences on carbohydrate metabolism in the CAM bromeliad Aechmea 'Maya': consequences for carbohydrate partitioning and growth. Annals of Botany, London, v.105, p.301-309, 2010.

COTE, F.X.; FOLLIOT, M.; ANDRE, M. Photosynthetic Crassulacean acid metabolism in pineapple: Diel rhythm of $\mathrm{CO}_{2}$ fixation, water use, and effect of water stress. Acta Horticulturae, Wageningen, v.334, p.113-129, 1993.

DAMASCENO E SILVA, K.J.; SOUZA, A.B.; GOMES, L.F. Effect of plantlet heights on post-in vitro-culture adaptation of ornamental pineapple. Revista Ceres, Viçosa, v.55, n.6, p.551-555, 2008.

DAQUINTA, M.; BENEGAS, R. Brief review of tissue culture of pineapple. Newsletter of the pineapple Working Group, International Society Horticultural Science. Hawaii, v.3, p.7-9, 1997.

ESCALONA, M. et al. Pineapple micropropagation in temporary immersion system. Plant Cell Report. Berlin, v.18, p.743-748, 1999.

FILA, G. et al. Relation between leaf conductance to $\mathrm{CO}_{2}$ diffusion and photosynthesis in micropropagated grapevine plants, before and after ex vitro acclimatization. Journal of Experimental Botany. Oxford, v.57, n.11, p.2687-2695, 2006. 
GONZALEZ-OLMEDO, J.L. et al. New contributions to propagation of pineapple (Ananas comosus L. Merr.) in temporary immersion bioreactors. In Vitro Cellular and Developmental Biology-Plant, London, v.41, n.1, p.87-90, 2005.

HERRERA, A. Crassulacean acid metabolism and fitness under water deficit stress: if not for carbon gain, what is facultative CAM good for? Annals of Botany,

Wageningen, v.103, p.645-653, 2009.

KITTO, S. Commercial micropropagation. Hort Science, Alexandria, v.32, n.6, p.1012-1014, 1999.

KELLER, P.; LÜTTGE, U. Photosynthetic light-use by three bromeliads originating from shaded sites (Ananas ananassoides, Ananas comosus cv. Panare) and exposed sites (Pitcairnia pruinosa) in the medium Orinoco basin, Venezuela. Biologia Plantarum, Prague, v.49, n.1, p.7379, 2005.

\section{LEAL, F.; COPPENS 'EECKENBRUGGE, G. The} Pineapple. In: JANICK, J.; MOORE, J.N. Fruit Breeding. Tree and Tropical Fruits. John Wiley and Sons Inc. 1996, v.1, p. 515-556.

LOEILLET, D.; DAWSON, C.; PAQUI, T. Fresh pineapple market: from the banal to the vulgar. Acta Horticulturae. Wageningen, v.902, p.587-594, 2011.

MURASHIGE, T.; SKOOG, F. A revised medium for rapid growth and bioassay with tobacco tissue culture.

Physiologia Plantarum. Prague, v.15, p.473-479, 1962.

NIEVOLA, C. et al. Temperature determines the occurrence of CAM or $\mathrm{C} 3$ photosynthesis in pineapple plantlets grown in vitro. In Vitro Cellular and Developmental BiologyPlant. London, v.41, p.832-837, 2005.
PORRA, J. The chequered history of the development and use of simultaneous equations for the accurate determination of chlorophylls a and b. Photosynthesis Research. Prague, v.73, p.149-156, 2002.

SEON, J.H. et al. Influence of in vitro growth conditions on photosynthetic competence and survival rate of Rehmannia glutinosa plantlets during acclimatization period. Plant Cell Tissue Organ Culture. Dordrecht, v.61, p.135-142, 2000.

SILVA, A.B. et al. Natural light in pineapple (Ananas comosus L. Merr.) micropropagation. Interciencia. Caracas, v.33, p.839-843, 2008.

VILLALOBO, A. et al. Effect of substrate volume and foliar fertilization on morpho-physiological changes in 'MD-2' pineapple plantlets. Newsletter of the Pineapple Working Group, International Society. Hawaii, v.19, p.30-31, 2012.

WATT, M.P. The status of temporary immersion system (TIS) technology for plant micropropagation. African Journal of Biotechnology, v.11, n.76, p.14025-14035, 2012.

YANES, E.; GONZÁLEZ-OLMEDO, J.L.; RODRÍGUEZ,

$\mathrm{R}$. Light management during acclimatization of Pineapple (Ananas comosus (L.) Merr.) cv. Cayena lisa 'Serrana' Vitroplants. Newsletter of the Pineapple Working Group, International Society. Hawaii , v.7, p.3-5. 2000.

\section{ZHU, J.; BARTHOLOMEW, D.P.; GOLDSTEIN, G.}

Photosynthetic gas exchange and water relations during drought in 'smooth cayenne' pineapple (Ananas comosus (L.) Merr.) grown under ambient and elevated $\mathrm{CO}_{2}$ and three day/night temperatures. Acta

Horticulturae. Amsterdam, v.666, p.161-173, 2005. 